\title{
Human Needs Satisfaction and Conflict Prevention in Africa
}

\author{
Anne Abaho \\ Nkumba University, Entebbe, Uganda \\ Email: aabaho@nkumbauniversity.ac.ug
}

How to cite this paper: Abaho, A. (2020)

Human Needs Satisfaction and Conflict Prevention in Africa. Open Journal of Social Sciences, 8, 1-17.

https://doi.org/10.4236/jss.2020.81001

Received: October 12, 2019

Accepted: December 28, 2019

Published: December 31, 2019

Copyright $\odot 2020$ by author(s) and Scientific Research Publishing Inc. This work is licensed under the Creative Commons Attribution International License (CC BY 4.0).

http://creativecommons.org/licenses/by/4.0/

\begin{abstract}
This article reviews literature concerning the conflict prevention strategies in some African countries. The article acknowledges that there have been numerous efforts: mediation, negotiations and military involvement employed in ensuring that the conflicts do not break out or are reignited on the continent. Nonetheless, the conflicts have remained a continental problem. This work argues that despite the commitment to preventing the conflicts on the continent, unless human needs are satisfied, the efforts may as well go to waste. Thus, using the Human Needs Theory, this paper argues that the frustration of human needs has a direct relationship with conflicts outbreak. The paper recommends adopting the Human Needs Theory to conflict prevention strategies as critical for proper diagnosis of the conflict triggering factors on the continent.
\end{abstract}

\section{Keywords}

Conflict, Conflict Prevention, Human Needs, Africa

\section{Introduction}

Africa has, since independence witnessed a series of armed conflicts with the worst coming from the Sub-Saharan region. True, conflicts in countries like Chad (1965-85), Liberia (1980-2003), Nigeria (1967-70) Rwanda (1994) and Sierra Leone (1991-2001) speak volumes about the security situation in the continent. Indeed, [1] documented that in the last ten years, the region has witnessed the highest number of people suffering insecurity and fear of violence. Undoubtedly, in countries like Angola, Uganda, Sudan and Somalia, to mention a few, conflicts have, despite the ending of the Cold War persisted for quite a long time. Interestingly, these conflicts are not occurring between or among countries but are rather of intra-state nature. Such a scenario challenges the 
post-World War II view that prevailing conflicts were due to ideological differences triggered by the East-West tension [2]. Undoubtedly, these conflicts have often left the continent's inhabitants with major socio-economic effects such as life loss, displacement and increased poverty levels [3]. Conflict is not necessarily Africa's unique feature-conflicts in Bosnia, Serbia, Turkey, Northern Ireland, Cambodia, Iraq indicate a troubled world indeed [4]. However, as [4] further explained, what makes Africa distinct is the regularity of the conflict outbreaks. Without doubt, these conflicts call for an urgent international and regional commitment to resolving and preventing them lest they continue obstructing human development [1]. This article therefore reviews literature relating to the conflict prevention strategies in Africa with a view that unless the strategies adopt a Human Needs Theory, they are in vain. The following section provides a brief description and review of conflict prevention and the strategies used in Africa.

\section{Literature Review}

\subsection{Conceptual Analysis: Conflict Prevention}

Conflict prevention refers to a wide range of measures: actions, interventions, programs and activities that are undertaken to address structural threats and prevent the escalation of tension into violent conflict. The major purpose for conflict prevention activities, as recorded by [1] and [5] is to ensure that conflict doesn't recur as well as reduce violent conflict. Equally, conflict prevention aims at making societies resilient to violent conflict by equipping the local population with skills and competencies to deal with conflict triggers. Conflict prevention as a concept is recorded to be different from other peacebuilding concepts and approaches depending on when it is incorporated in the conflict cycle. The [3] explained that early conflict prevention strategies aim at improving the relationship between/among parties before conflict actually breaks out while late initiatives aim at resolving the conflict and curtailing the driving forces from starting a new one.

\subsection{Conflict Prevention in Africa}

Practically, there is commitment and enough resources channeled to manage, reduce and end wars such that post-conflict stability can be ensured [1]. However, as [1] noted, conflict prevention is complex, frustrating and at times expensive that even with the best efforts, the risks of failure remain rather high. This notwithstanding, the efforts to prevent conflicts and their resurgence in Africa are historical. In the recent times, however, the example of Kenya (2008) with Kofi Annan at the forefront of the African Union mediation efforts are remarkable. Indeed, as the political opponents were forging a political solution, the United Nations, in support of the Union deployed political officers, electoral, constitutional and security experts as support staff for the mediator [6]. Despite the settlement, violence broke out again in 2017 following contested election re- 
sults causing massive destruction of public infrastructural facilities such as health centres and schools as well as loss of life [7]. In Sierra Leone, a United Nations (UN) peace-building mission struggled to save the country from relapsing into conflict and saving the country's hard-fought peace [6]. Established in June 1998, the United Nations Observer Mission in Sierra Leone (UNOMSIL) was tasked with monitoring and disarmament functions. To prevent further outbreak of conflict, the United Nations Mission in Sierra Leone (UNAMSIL), created in 1999 by Security Council Resolution 1270 helped in building infrastructure such as schools, supported voter education campaigns and remained in the country until 2005 [8]. In other African regions such as Southern Africa, leaders such as Thabo Mbeki are also known to have adopted a unique approach (Quiet diplomacy) in dealing with regional problems.

In 2011, following extensive consultations with regional players, the UN supported a referendum in South Sudan. To avoid a lapse into conflict, Resolution 1996 on July 8th 2011 which, acknowledged that the South Sudan situation was still a threat to global peace and security was adopted. As such, a UN Mission in South Sudan was established with the mandate to support peace, support long term State building and economic development [9]. Unfortunately, the conflict has dragged on threatening many lives, destroying property and limiting any possibility of meaningful State and economic development.

Considering the porous nature of borders on the continent, the military has at times been preferred when non-military efforts such as ceasefire and sanctions have failed. This approach is in line with the UN's concept of collective security as narrated in Chapter VII of the International Organization. Article 39 of the Charter provides that when peaceful means fail, the Security Council can, in order to maintain global peace and security in the face of an act of aggression or breach of the peace use force. Aware of the marginalizing UN system of Africa as a continent in the area of international peace and security, African leaders chose to depart from the limitations on the use of force as expressed in Article 2(4) of the Charter to preventing conflicts on the continent. Indeed, the actions by ECOWAS in rescuing the Liberian situation through military efforts was illustrative of the new move by African leaders. Thus, through its military wing, ECOMOG, five thousand troops were sent to keep peace and restore order while ensuring that a ceasefire between the rebels and government was held [10].

In Burkina Faso, following violent protests in 2014 against the then President Blaise Campaore, the country slid into political turmoil when members of the former presidential guard organized a coup against the transitional government [11]. Fortunately, the United Nations Regional Office in West Africa (UNOWA) together with the Economic Community for West African States (ECOWAS) diplomatically worked to dissuade Campaore out of office. This was followed by a series of efforts to ensure dialogue among the parties as facilitated by the UN Secretary General Representative; Mohamed IbnChambas in cooperation with ECOWAS and African Union. Continued engagement with the political players saw the peaceful election of Christian Kabore of the People's Movement for 
Progress as president.

From the illustrations above, it is clear and evident that enough effort has been dedicated to preventing conflicts in Africa. The players have been not only regional such as ECOWAS but also continental (AU) and global (UN) through the UNSC. However, these efforts have largely remained political with chances of renewal of violence being high. It is on this basis that the paper argues for a shift in strategy in order to ensure a successful end to conflict-addressing the needs of population. This strategy diverts from the traditional objectives of conflict prevention that often seek to restore the functionality of the State by ensuring economic production and physical security provision [12] as opposed to addressing the fundamental human requirements that make life meaningful and valuable while deterring man from engaging in destructive character. In the section that follows, literature relating to Human Needs Theory is reviewed with an intension of justifying its (Human Needs Theory) adoption in conflict prevention.

\section{The Human Needs Theory and Conflict Prevention: Applicability}

"But the first and the greatest of our needs is the provision of food to support existence and life... the second the provision of a dwelling-place, the third, of clothing, and so on" [13]

The above caption is an ancient philosophical thinking that reveals how hierarchical human needs are in nature. While there are arguments that human needs cannot be organized and satisfied in a hierarchical manner for none should be placed above the other, the quotation reveals a historical recognition that human beings need certain needs to feel secure. A similar ranking seems to happen in related studies such as in the human security discourse where, for example [14], while referring to Leaning and Arie proposed three key measurable components of human security as: a sustainable sense of home, constructive social and family networks, acceptance of the past and positive grasp of the future. The absence of these needs creates an insecure man, whom as [15] explained can no longer be sure of the future. For the reader to appreciate how frustration of the basic needs can cause insecurity and thus lead to outbreak of conflict, it may be necessary to understand how Human Needs Theorists' views are helpful in preventing conflict.

\subsection{Lewis Coser's Social Conflict Theory and the Birth of the HNT}

In 1956, [16], wrote a book: The Functions of Social Conflict in which he used the term; realistic conflicts attributing them to frustration of specific demands and directed towards the frustrating object. Growing out of a doctoral dissertation under the guidance of Robert K. Merton at Columbia University, the text gained a wide appreciative audience in the United States following the Civil Rights Movement of the 1960s [16]. Although the text said very little on the 
ending of conflict, Coser, a refugee from Germany during the conflict laden years of the Weimar Republic and a formerly Internally Displaced Person in the French Camp thought that it would address the balance by focusing attention on the central importance of social conflicts in social structures and human affairs. Using the Social-Conflict Theory, Coser argued that conflicts are not necessarily destructive because they can foster social cohesion by identifying social problems to be overcome.

Coser's work contributed and influenced significantly other sociologists among whom was Abraham Maslow and John Burton that later adopted the Human Needs Theory in studying conflicts. While Maslow is known for having used the approach to understand the human mind and how/what motivates it, Burton used it to study conflict. The Human Needs theorists hold that they are inclusive of both physical and non-physical elements such as food, water and shelter and those that human beings are inherently driven to attain.

Maslow explained this relationship thus:

"It is easy to accept basic need frustration as one determinant of hostility, it is quite as easy to accept the opposite of frustration, that is basic need gratification, as an a priori determinant of the opposite of hostility, that is friendliness" [15]

Unfortunately, human needs are often destroyed during the conflict phase complicating the process of post-conflict recovery and grooming a fertile ground for fresh conflicts. Yet, as [17] warned, one ought to be careful in the delivery of these basic needs. For example, the provision of water without accounting for vulnerable women and girls may as well reinforce social and cultural divisions that in turn inform a rebirth of conflict.

The relevance of human needs in averting the resurgence was confirmed by [18] remarking that:

"Human needs theorists offer a new dimension to conflict theory... approach provides an important conceptual tool that not only connects and addresses human needs on all levels. Furthermore, it recognizes the existence of negotiable and non-negotiable issues.... needs theorists understand that needs, unlike interests cannot be traded, suppressed or bargained..."

For clear comprehension of the influence of human needs satisfaction in conflict prevention, it may be necessary to review a key theorist Abraham Maslow's idea on the hierarchical ordering of these needs. Throughout the paper, effort shall be made to show how absence of these needs may quickly trigger conflict but satisfaction of the same may as well be beneficial in conflict prevention.

\subsection{Abraham Maslow and the Human Needs Theory (HNT)}

Abraham Maslow saw human needs in form of a hierarchy ascending from the lowest to the highest [19]. The needs, according to Maslow range from Physiological (food, water, warmth, shelter and sleep), security or safety (free from danger and the fear of job loss, property, food or sleep), affiliation or acceptance (social needs-belong and be accepted), esteem (power, prestige, status and 
self-confidence) and self-actualization (what one is capable of becoming-maximization of potential) needs. Figure 1 overleaf captures not just the needs but also their hierarchy as suggested by Maslow.

According to [20], the lower four levels of the pyramid reveal "deficiency needs" since one may not feel anything if they are not met but their absence makes one anxious. Physiological needs such as food and water as well as shelter are deficiency needs and so are safety ones and acceptance needs. Meantime, the fifth level of the pyramid can only be realized by a few people since it requires uncommon qualities such as honesty, independence, awareness, objectivity and creativity. Maslow's historic theory is universal and cuts across through development and security discussions. Indeed, the theory has been appreciated by international organizations and researchers such as [21] in its Human Development Report when it acknowledged that:

"... a powerful idea that provides the philosophical foundations for many contemporary policies-underlies the search for meeting basic human needs... it demands a world where no child goes without an education, where no human being is denied health care and where people can develop their own potential capabilities".

Without necessarily ignoring the relevance of the fourth and fifth levels, this work shall endeavour to relate the components of the first three levels of the pyramid to conflict prevention. This is in light of the view that esteem and self-actualization (fourth and fifth pyramid respectively) after all, may be dependent on one's feeling of safety and or satisfaction attained from accessing the physiological welfare components. This view was confirmed in [19] that:

"... if these fundamental needs are met, then an individual can focus upon higher needs such as self-esteem and respect, eventually reaching a metamotivated state... in this state, an individual achieves self-actualization and can focus upon the development of the self by way of creativity, morality, acceptance and the loss of prejudicial perspectives".

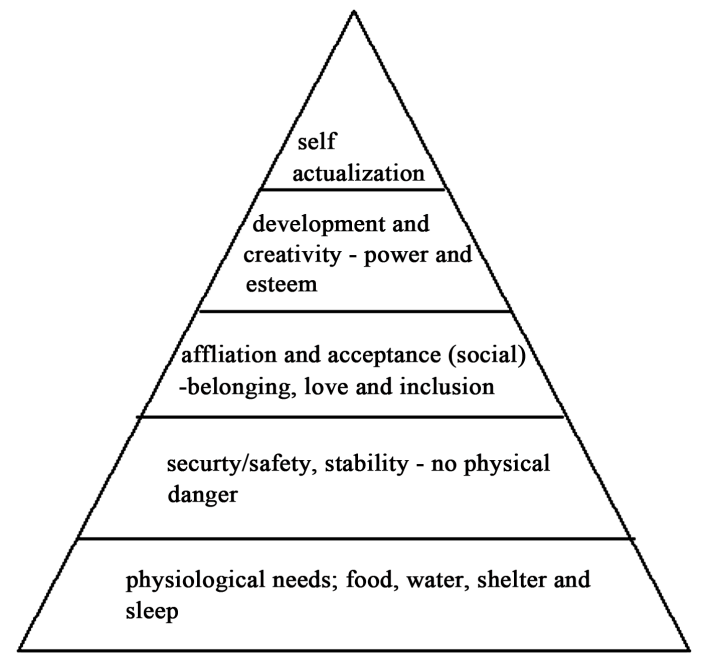

Figure 1. Maslow's hierarchy of needs. Source: [20]. Our hierarchy of needs. 


\subsubsection{Physiological Needs and Conflict Prevention}

[22] observed that: to put economic growth on a firm foundation, societies must meet the basic human needs of most of the population. Thus, people need food, shelter and other necessities of daily life in order to feel secure. Interestingly, the observation made by the duo had and has increasingly been given support by other researches; [21] [23] [24] [25] among others. For example, the [24] observed that:

"improved nutrition increases the capacity to earn and produce, and the income earned provides the means to buy food. Having access to adequate food affects people's ability to participate in all spheres of economic, political and social life and to move out of chronic poverty."

Without doubt, participation in all spheres allows human security to thrive and human focused development to take place. Such development can be a recipe in preventing violent conflict for it allows addressing the underlying issues in the course of the conflict while leaving room to address the conflict driving factors in the process of recovery [17]. This work agrees with [24] that the value of basic needs is significant only when one can go beyond for example, feeding but be able to be productive for purposes of securing the future.

[4] recommended that for the African continent to rid itself of conflict, there should be a deliberate focus on poverty eradication. This, the writer argued is attributed to the fact that a poor man who has been economically humiliated and financially traumatized may not be able to act in his right senses. Humiliated, a poor man can steal, kill, maim and destroy. Unfortunately, just as dissatisfaction of basic needs can lead to conflict, so too does conflict destroy the existing basic needs infrastructure.

With an already underfunded and strained infrastructure, conflicts in the developing world have painted a gloomy one. For example, in 2004, UNICEF found that one in six children suffered severe hunger, one in seven lacked access to health care and one in five had no access to clean environment. These statistics do compromise the possibility of living a dignified and secure life. Unfortunately, children are central in a nation's development and progress as well as meeting of its basic needs. [22] documented for example that:

"education allows a new generation to meet other basic needs and move through the demographic transition... that a person who can read and write can obtain wealth of information about farming, health care, birth control and so forth..."

Despite the fact that basic needs are key in determining one's level of happiness, contentment and feeling safe, the condition in Africa gives a blurred image. The continent, according to [26] has consistently remained among the top places for conflicts: both intra and inter-state yet, despite the lack of basic social services, the military are often well financed and equipped. This image falls short of the visions of the post-independence African leaders such as Nyerere and Kaunda who called for a dignified life for the African through their philosophies of Ujaama and humanism respectively. But this is not shocking for the African 
State borrows its history and existence from European politics of Administration that is rooted in Westphalian thinking.

It is worth noting that the absence of basic needs is an indication of collapse of basic service delivery which in turn affects the wider development agenda [27]. Yet, failure to create good service delivery systems may actually increase the risk of return to conflict especially as State capacity to avert a new conflict is weakened, resources are diverted to cater for military interests and/or infrastructure itself is/was destroyed by the conflict. [17] confirmed that needs such as education and health have an important role in either ending conflicts or exacerbating them. For example, the authors noted that if access to education services follows patterns of exclusion, tension often becomes rife. Certainly, when the individual feel excluded, the response behaviour may turn out negatively.

\subsubsection{Security/Safety Needs and Conflict Prevention}

Maslow documented a long list of human security/safety threats ranging from apprehensiveness, fear, dread and anxiety, tension, nervousness and jitteriness. He further explained that; whatever words we use, there is a character difference between the man who feels safe and the one who lives his life out as if he were a spy in an enemy territory... [15] Unfortunately, lack of security doesn't only affect the individual directly but also the other security dependent sectors such as the economy. For example, [27] acknowledged that when physical security is lacking, it is likely to deter local and foreign investors. It is worth observing that economic sluggishness and underdevelopment is an incentive for conflict. Indeed, as [28] noted, using the econometric model developed by the World Bank, countries per capita income is at $\$ 250$ has a high possibility of war despite being considered an average country. The author explained that as the country's Gross Domestic Product (GDP) increases to for example $\$ 600$, its chances of war reduce by half and further reduces by half when it increases to $\$ 1250$. Certainly, the economy determines the possibility of young unemployed males to be recruited into soldiering activities. Quoting Collier \& Hoeffler, the [25] explained that:

"The potential costs may include being captured, imprisoned, killed or wounded. The benefits of joining a rebel group include access to food, guns, excitement, comradeship and the possibility of loot".

In Collier \& Hoeffler's statement, there is a revelation of a desire for fulfillment of the physiological needs that pushes the youth into recruitment-this unfortunately may worsen in the post-conflict environment paving way for renewed violence. This explains why studies such as [29] advocated for a broader approach to recovery that achieves social economic well-being including restoring citizen and societal security, ensuring food security, restoring shelter and public health, educational systems and generation of employment and re/opening markets. Unfortunately, the political situation in Africa dictates that those who have access to and control power thus assume a take-all position. Such a primitive political situation provides a fertile ground for unhealthy com- 
petition for the available resources and opportunities. With the nature of African politics, it is less surprising to find that even after conflict, such critical sectors remain underfunded for so long. Yet, as [30] remarked, at whatever level and regardless of the degree of intensity, conflict becomes violent over the irrational management and distribution of resources.

[31] explained that by security and/or safety needs of the individual, focus is on the reduction of physical threats to personal safety including protecting people and their livelihoods and providing a foundation for them to ensure progress in other dimensions of development. Fresh minds in the discussion on human needs may critique the entry of development into the subject matter. This however, cannot escape mention because of the inextricable link between security and development. Indeed, [5] explained that conflict prevention must be mainstreamed in all development strategies in order to avert the structural causes of conflict. These causes were identified as group inequalities, poverty and exclusion of certain groups. At the risk of mentioning the obvious, these causes threaten the realization of human needs. Frustration of the mentioned basic needs, undoubtedly is reason enough to spark off conflict.

Not surprising, [32], in explaining the relationship between basic needs and human security hinted on poverty and its impact on human development. An individual's socio-economic status is a strong contributing factor to participation in conflict. For example, [33] recorded that while individuals may be involved in conflict involuntarily, others are motivated to take part because of the monetary benefits attained through looting and appropriation of valuable assets. Thus, the support to conflict groups whether voluntarily or otherwise may be explained by the desire to guarantee some level of fulfillment of basic needs. Noting that conflict can be triggered and sustained by those that are economically challenged despite the likely human costs (death for example), it is valuable for any conflict prevention strategies to address poverty as a motivating factor in conflict break-out. The relationship between poverty and conflict outbreak and the importance of addressing it was well narrated by [34] as such:

"Addressing poverty is not just a matter of doing the right thing-it is a matter of doing the smart thing to ensure security at home and abroad. By exhausting institutions, depleting resources, weakening leaders and crushing hope, extreme poverty fuels instability that often leads to armed conflict and can be a breeding ground for terrorists..."

[31] widened the concept of safety to include a foundation on which long-term, sustainable development can be built arguing that there is an unbreakable interdependence between security and development. The trio's view is wide enough to cater for freedom from want and fear that can influence the outbreak and sustenance of conflict. [35] distinguished between structural and triggering factors to conflict. Triggering factors, although seen to work in the contest of structural factors included abuse of political and military power, proliferation of arms and ideological differences. Structural factors were listed to comprise a wide range of political, social and economic elements such as population 
pressure, distributional injustice, natural resource depletion but above all failure to meet basic human needs.

[36], in a tone related to [31], asked what the prospects of peace building are in post-war societies beset by in(security) problems? Like many liberal thinkers, Morgan challenged the State-centric approach to security. She documented:

"In most cases of peace building (reconstruction after conflict termination), it is the integrity of the state that is often given security... as a result of this unidimensional, state-centric view of security, many states confronted with civil strife have been unable to resolve their difficulties... many peace-building efforts undermine the emphasis on human security because people are viewed as the means to political stability as opposed to being the end of all peace-building efforts" [36]

De-securitizing the individual in post-conflict setting, doesn't only affect his/her enjoyment of human security but it also narrows the chances of enjoying lasting peace. Traditionally, the security of the individual has been equated to the security of the State. This narrow and unidimensional view is problematic as it wraps human security with State security and limits chances to discuss the social, economic and political threats to human security. Indeed, Maslow widely considered the security and safety needs to range but not limited to absence of a physical danger and the fear of job loss, property, food and shelter. This widened angle of needs falls in a similar net with the widened view of security that includes freedom from fear and freedom from want. Enumerated upon by the [21], the concept: freedom from fear and freedom from want is now the widest used approach to security [31]. In 2007, Amnesty International, in explaining the impact of fear on human security realization observed that: fear destroys our shared understanding and our shared humanity [23].

The Human Needs Theory therefore serves as well in the enhancement of human security for it doesn't only emphasize the physical security of the individual but fulfils as well the aspect of freedom from want. Because of its inclusive and human based nature, it equally gives man the chance to exploit the opportunities available in creating a stable society.

\subsubsection{Social Needs (Affiliation and Acceptance) and Conflict Prevention} Many conflict ridden and post-conflict countries are often characterized by features of mistrust and high levels of social distance among the different groups [24] [25]. Bearing this in mind, it is necessary for conflict prevention and post-conflict recovery efforts to foster an environment that cultivates a culture based on tolerance, cooperation and fairness. This is necessary in order to demystify images of "we" and "them" that may have in the first place led to conflict and prevailed during the conflict years. [15] further explained the place of the third level of the pyramid when he noted:

"Just as a tree needs food, sun, water from the environment, so does the person need safety, love and respect from the social environment... this is just where real development that is of individuality begins. All trees need sunlight 
and all human beings need love and yet, once satiated, with these elementary necessities, each tree and each human being proceeds to develop in his own style, uniquely using these universal necessities to his own private purposes. In a word, development then proceeds from within rather than from without".

From Maslow's explanation, it is evident that man needs social support in order to develop-to realize his/her full potential. Underscoring the importance of social support doesn't mean that human beings cannot develop on their own. On the contrary, as the [21] observed,

"Human beings are born with certain potential capabilities. The purpose of development is to create an environment in which all people can expand their capabilities for both present and future generations".

Critical to note is that there is a self-sustaining cycle between conflict and human under-development. Conflict certainly destroys physical and human capital just as it kills institutional capacity to meet and fulfill the obligations [37]. A combination of these factors equally leads to human under development. The authors [37] noted that societies with low levels of human development have difficulties in improving productivity and in turn, lower growth rates increase the risk of conflict.

Worth considering is the importance of social networks in ensuring support during crises. As the [24] explained, such networks are constructed on patterns of social solidarity that over time evolve at the grass root levels. Social networks, the [24] elaborated are strengthened through giving communities access to basic social infrastructure and income. Unfortunately, this highly recommended social network that fosters belonging may be a dream in Africa especially in conflict ravaged countries. For example, [23] elucidated that:

"The realization of economic, social and cultural rights have remained illusory in almost all African countries. Struggling economies, under-development, under-investment in basic social services, corruption and marginalization of certain communities were some of the factors behind the failure to realize basic human rights..."

It goes without saying that ignoring the social service sector whether in Africa or elsewhere is not only a curtailment on the enjoyment of internationally recognized human rights such as health and education but also a recipe for insecurity. Thus said, human beings especially in the post-conflict environment need to feel a sense of belonging (often which is affected as a result of displacement and loss of loved ones). Indeed, when the [38] interviewed formerly displaced persons about the effect of the experiences of their past on their present psycho-social wellbeing, many connected their individual knowledge to the community's social life and livelihoods. The Network, in an effort to elaborate the views documented:

"While most respondents identified the need for basic food, health, shelter, and security, the majority expressed concern about how these needs were being met....they linked personal notions of distress to their external social domain rather than to their inner psychological world..." [38] 
Maslow, without doubt defended the need for social relations and a sense of belonging - this anyway creates a fair imagination of safety of the being. The relevance of social relations goes beyond the individual to cater for the whole society. After all, the individual is part of the wider social network. This is confirmed in [32] who elucidated that when sociologists or anthropologists discuss basic human needs, the focus is almost always beyond the level of the individual, on Basic Human Needs connected to the functional requirements of the larger cultural systems...

Exclusion, it is notable is a source of insecurity and so is in access to power and resources. Indeed, [3] documented that patterns of marginalization and exclusion are critical in understanding future conflicts. The Agency expressed that exclusion especially when political is often a curtailing factor to long-term economic development and thus a trigger for conflict. For Maslow, it is not political but social exclusion that hampers the realization of social security and affects the individual's self-esteem and attachment to a social group. Such security can only be given by humans to fellow humans for it is:

"from another human being that we can get fully satisfying respect and protection and love, and it is only to other human beings that we can give these in fullest measure... these are the very satisfactions that we seek from good human relationship of any kind... these are the preconditions for the production of good human beings which in turn is the ultimate (if not immediate) goal of all..." [15].

Notable, this section has, while concentrating on the first three core levels of the pyramid analysed Maslow's Hierarchy of Needs (HoN) as advanced in his Human Needs Theory. Ultimately, the task was to elaborate on how the fulfilment of these human needs can influence conflict prevention. The list of needs, however has since been modified and widened. Indeed, as the next section indicates, from the 5 key pyramids, Paul Sites listed the needs as eight while Burton widened them to nine. As [39] explained, much of the work on human needs in conflict resolution is founded upon the works of Maslow, Sites and Burton. [39]'s explanation links clearly with the next section's task: discussing the views of Sites and Burton while justifying the relevance of human needs in conflict prevention.

\subsection{From Abraham Maslow to Paul Sites (1926-2010)}

As earlier discussed, while Coser used the approach to study the social aspects of man and the causes of conflict, Maslow adopted it to understand man's psychological character and the possible results of unfulfilled needs. Sites did not only widen the list of needs but he equally argued that they are universal.

In his 1973 text, Control: The Basis of Social Order, Sites, adding to the extensive research by Maslow, proposed a list of 8needs as: response, security, recognition, stimulation, distributive justice, meaning, to be seen as rational and a need to control. Sites argued that: basic needs do exist and that they are universal, and thus less specifically cultural than some behavioural scientists would 
have us believe [40]. In his view, the strongest of all needs is Control for with it one doesn't only control his environment but also the satisfaction of a host of other needs. Sites, in explaining how unmet human needs can contribute to conflict reinforces Maslow's view that:

"the individual who is exposed to a high degree of inconsistency in response may develop schizophrenia... these illnesses may occur in any situation where the individual is not able to control the situation from what he sees as a rational, that is means-ends consistency, point of view" [40]

In Sites' View, needs do not end with the individual but also extend to the group. This individual-group need interaction cuts across to human security in which the security of the individual affects that of the group. Indeed, as the CHS elaborated on the instrumental role of health, it is not just personal but also collective. The Commission noted:

"Health's instrumental role is collective as well as personal. Good health is a precondition for social stability. Sudden outbreaks of a contagious disease or other health crisis can destabilize an entire society" [24]

From the above, when the Human Needs Theory is adopted in conflict prevention strategies deliberate effort can be concentrated on restoration of basic needs to avoid renewed violence. Such a strategy is key in safeguarding the individual's life from pervasive threats such as abuse of human rights, structural injustice and poverty.

Notable, societies affected by war do not only suffer shortages in basic needs but may also develop a culture of violence as a result of unmet needs. Indeed, the [41] documented that even after conflict, there remains looming uncertainty due to shortages in basic services and settlement space. Hence, a Human Needs Theory adopted in conflict prevention can help lay emphasis on engaging all communities into dialogue to address the real needs, the effects of displacement, the imprints of war and people's ideas on how best to move forward [42].

\subsection{From Paul Sites to John Wear Burton (1915-2010)}

According to [42] John Burton became closely identified with the Needs Theory since the publication of his book: Deviance, Terrorism and War: The Process of Solving Unsolved Social and Political Problems in 1979. [43] confirmed Rubenstein's view that Burton reconstituted the conflict analysis agenda when he challenged the Statist and State-centric views to understanding and resolving conflict. Dunn wrote in reference to Burton's 1979 work that:

"We are concerned with process, not status or structures. We are concerned with the solving of social and political problems, not their containment, management or control. We are also concerned with change and not coercion, either to effect change or to resist it. Moreover, we are concerned with recurrent patterns of human behavior at all levels of social complexity".

Burton, borrowing from Abraham Maslow's Human Needs Theory and Sociologist Paul Sites' lists of needs revolutionized the Human Needs Theory to study conflict and conflict resolution. To Burton, this combination is what he 
called: a unified theory of human behaviour that he linked to conflict studies. Born in Melbourne, he graduated in Psychology in Sydney University in 1937 and later joined the academia from 1955-1963 [44]. He widened the list of the needs to nine as: 1) consistence in response, 2) need for stimulation/response, 3) a need for security, 4) need for recognition, 5) need for distributive justice, 6) need to appear rational and develop rationally, 7) need for meaningful response, 8) need for sense of control, and 9) need to defend one's role. These needs, according to [45] are critical in averting conflict. Quoting Burton (1997: 19), Sandole documented:

"The reason why past compliance systems led to alienation and anti-social behaviour is now emerging. It is becoming clear that there are human limits to capacities to conform to elite-sponsored institutions and norms: the person is not wholly malleable. On the contrary, the needs that are frustrated by institutions will be pursued in one way or another. These needs would seem to be even more fundamental than food and shelter. Individuals are prepared to go to extreme lengths to defy systems in order to pursue their deeply felt needs, even death..."

For Burton, these needs are ontological-universal and inherent in the individual. By describing them as ontological, Burton doesn't only push for the possibility of putting values (which are culturally learned) above needs but also challenges the traditional International Relations views that conflicts can be deterred-the deterrence Theory. Instead, Burton uses the Palestinian conflict in which deterrence theories have not challenged the desire for universal human needs such as desire for a sense of belonging, security and recognition [44]. From the Palestinian conflict analogy thus, Burton's theory relates strongly yet remains different from Maslow's in a way that it challenges the hierarchical order of needs that the latter follows but agrees that certain needs are critical for human survival and frustration of the same causes conflict.

In a manner that borrows from Sites, he admits that with controls such as through creating reliable institutions, these needs can be met and the possibility of conflict averted. He wrote:

"We are asserting that if there were to be discovered a definite set of human needs on the basis of which societies could be harmonious, major methodological problems in behavioural sciences and in policy-making would be avoided. If there were agreement as to human needs then there would be a logical starting point of behavioural analysis for there would be a scientific basis for determining goals" [46]

Burton in a way, contradicting his earlier views (that needs are not hierarchical) argues that there are a set of needs (knowable) upon which a guide to understanding human behaviour can be developed and for policy makers to make decisions that control conflictual relationships. Thus in his view, appropriate institutions within a society can fulfill these needs for all parties and thus create sustainable peace [46]. It is the position of this research that these appropriate institutions can be all actors involved in conflict prevention such as Govern- 
ment, Civil Society Organizations and development partners among others. Above all though, by pointing at consequences of needs deprivation, Burton says Sites' Control Theory should be called Needs Theory because the former, after all focuses on how circumstances (deprivation of needs) create aggression.

For Burton, the limitations to man's development and the causes of a conflictual society result from deprivation of certain needs. This is natural and inherent in man (Realism for example holds that man's aggressive nature is responsible for global conflict). Unfortunately, realists' views on deterring conflicts (using force) do not appreciate the human needs frustration element that cannot be deterred by forceful means.

\section{Conclusion}

This work acknowledges the inconsistence in the list of needs (Maslow listed five, Sites mentioned eight while Burton recorded nine). The researcher equally submits that an indefinite list of needs would render the Theory's list too long and wide and can in turn mean anything and everything. The charges notwithstanding, adopting the Theory to explain International and Security phenomena will be a positive development in Conflict Studies. Conclusively, this work recommends a shift from the traditional conflict prevention strategies of restoring order between/among the conflicting authorities to adopting a Human Needs approach. Fortunately, scholars such as Johan Galtung, used the Theory to explain conflict but took it a notch higher when he distinguished between structural (injustice and exploitation built into a social system that cultivates wealth for few and poverty for many; cultural (prevailing attitudes and beliefs that justify structural violence-superiority/inferiority feelings; and direct violence (war, murder, rape, assault). In view of this research, traditional approaches are limited and narrow as they don't appreciate the centrality of human needs in frustrating peace efforts and reigniting violence. Additionally, the mainstream conflict prevention efforts are State centric and majorly interested in achieving a political answer to the conflict triggers. Such political answers can only provide short-term stability as frustration of the needs creates a breeding ground for fresh violence.

\section{Conflicts of Interest}

The author declares no conflicts of interest regarding the publication of this paper.

\section{References}

[1] Green, O., Buxton, J. and Paternak, S.C. (2006) Conflict Prevention, Management and Reduction in Africa. Centre for International Cooperation and Security, Helsinki.

[2] Mapendere, J. (2000) Track One and a Half Diplomacy and the Complementarity of Tracks. Culture of Peace Online Journalism, 2, 66-81.

[3] Swedish International Development Agency (SIDA) (2017) Conflict Prevention: 
Opportunities and Challenges in Implementing Key Policy Commitments and Priorities.

[4] Olaosebikan, J.A. (2010) Conflicts in Africa: Meaning, Causes, Impact and Solution. An International Multidisciplinary Journal, 4, 540-560. https://doi.org/10.4314/afrrev.v4i4.69251

[5] Franche, M.A. and Ebata, M. (2005) Conflict Prevention: Thematic Guidance Note. UNDP, New York.

[6] Pascoe, L. (2010) Rediscovering Preventive Diplomacy: A View from the UN. Remarks at the Brookings Institute.

[7] Ratner, B. (2017) Kenya: Post Election Killings, Abuse-Investigate Police Use of Excessive Force. Reuters.

[8] World Peace Foundation (n.d.) United Nations Mission in Sierra Leone (UNAMIL) Brief. African Politics, African Peace.

[9] Opiyo, O.J. (2012) The Challenges of Preventive Diplomacy: The UN's Post-Cold War Experience in Africa. African Journal on Conflict Resolution, 12, 61-82.

[10] Allain, J. (n.d.) The True Challenge to the UN System of the Use of Force: The Failures of Kosovo and Iraq and the Emergence of the African Union.

[11] United Nations (2016) UN Conflict Prevention and Preventive Diplomacy in Action: An Overview of the Role, Approach and Tools of the UN and Its Partners in Preventing Violent Conflict. Department of Political Affairs, UN, New York.

[12] Futamura, M., Newmann, E., Tadjbakhsh, S., Futamura, M., Newman, E. and Tadjbakhsh, S. (2010) Towards a Human Security Approach to Peace-Building. UN University-Institute for Sustainability and Peace, New York.

[13] Plato (1974) The Republic. 2nd Edition, Penguin Books, New York.

[14] Alkire, S. (2002) A Conceptual Framework for Human Security. Oxford University, Oxford.

[15] Maslow, A. (1970) Motivation and Personality. Harper \& Row Publishers Inc., New York.

[16] Coser, L.A. (1956) The Functions of Social Conflict. Brandeis University, Waltham.

[17] Vaux, T. and Visman, E. (2005) Service Delivery in Countries Emerging from Conflict. Centre for International Cooperation and Security, Department of Peace, University of Bradford, Bradford.

[18] Marker, S. (2003) What Human Needs Are.

[19] Koontz, H., O'donnell, C. and Weihrich, H. (1986) Essentials of Management. 4th Edition, McGraw Hill International, Singapore.

[20] Burton, N. (2012) Our Hierarchy of Needs.

[21] UNDP (1994) Human Development Report: New Dimensions of Human Security. UNDP, New York.

[22] Goldstein, S.J. and Pavehouse, C.W.J. (2009) International Relations, 2008-2009 Update. 8th Edition, Longman, New York.

[23] Amnesty International (2007) Amnesty International Report 2007: The State of World's Human Rights. The Alden Press, De Havilland Way.

[24] Commission on Human Security (2003) Human Security Now. UN, New York.

[25] Human-Security-Centre and Human-Security-Report-Project (2011) The Causes of Peace and the Shrinking Costs of War. Oxford University Press, Oxford.

[26] Mentan, T. (2014) Africa: Facing Human Security Challenges in the 21st Century. 
Langaa RPCIG, ProQuest Ebook Central.

[27] Brown, G., Langer, A. and Stewart, F. (2011) A Typology of Post-Conflict Environments. Centre for Research on Peace and Development, Leuven, CRPD Working Paper No. 1.

[28] Humpreys, M. (2003) Economics and Violent Conflict.

[29] Ohiorhenaun, E.J.F. (2011) Post-Conflict Recovery: Approaches, Policies and Partnerships. CRPD, Working Paper, 1-18.4.

[30] Olika, T. (2008) Conflict and Conflict Resolution in the Horn of Africa: Towards the Study of Regional Peace and Security. Ethiopian Journal of the Social Sciences and Humanities, 6, 1-24.

[31] Valters, C., Rabinowitz, G. and Denney, L. (2014) Security in Post-Conflict Contexts: What Counts as Progress and What Drives It? Development Progress, Working Paper 4.

[32] Avruch, K. and Mitchell, C. (2013) Conflict Resolution and Human Needs: Linking Theory and Practice. Routledge, New York. https://doi.org/10.4324/9780203098219

[33] Justino, P. (2011) Poverty and Violent Conflicts: A Micro Level Perspective on Causes and Duration of Warfare. IDS Working Paper 385. https://doi.org/10.1111/j.2040-0209.2011.00385_2.x

[34] Brainard, L. and Challot, D. (2012) The Tangled Web: The Poverty-Insecurity Nexus. Brookings Global Economy and Development.

[35] Willets, S. (2001) Insecurity, Conflict and New Global Disorder. IDS Bulletin, 32, 35-47. https://doi.org/10.1111/j.1759-5436.2001.mp32002004.x

[36] Morgan, C.E. (2005) Peace Building and Human Security: A Constructivist Perspective. International Journal of Peace Studies, 10, 69-86.

[37] Conceicao, P. and Kim, N. (2010) The Economic Crisis, Violent Conflict and Human Development. International Journal of Peace Studies, 15, 29-43.

[38] Humanitarian Policy Group (2006) Humanitarian Practice Network. Humanitarian Exchange. 36.

[39] Tidwell, C.A. (1998) Conflict Resolved? A Critical Assessment of Conflict Resolution. Continuum, New York.

[40] Sites, P. (1973) Control: The Basis of Social Order. Dunellen Press, New York.

[41] United-Nations-High-Commissioner-for-Refugees (n.d.) A Time between: Moving on from Internal Displacement in Northern Uganda.

[42] Rubenstein, E.R. (2001) Basic Human Needs: The Next Steps in Theory and Development. International Journal of Peace Studies, 6, 51-58.

[43] Dunn, J.D. (2001) John Burton and the Study of International Relations: An Assessment. International Journal of Peace Studies, 6.

[44] Steinmeyer, K.J. (2017) An Examination of John Burton's Method of Conflict Resolution and Its Applicability. University of South Florida, Tampa.

[45] Burton, W.J. and Sandole, D. (1993) From Strategic Deterrence to Problem Solving. In: Kevin, C., Ed., Peace and Security in the Asia Pacific Region, United Nations Press, Tokyo, 365-377.

[46] Burton, W.J. (1979) Deviance, Terrorism and War. St. Martins Press, New York. 